\title{
PENGARUH VARIASI KOMPOSISI GLISEROL DENGAN PATI DARI BONGGOL PISANG, TONGKOL JAGUNG, DAN ENCENG GONDOK TERHADAP SIFAT FISIS DAN MEKANIS PLASTIK BIODEGRADABLE
}

\author{
Oleh: \\ Inayatul Wardah ${ }^{1}$, Erna Hastuti ${ }^{2}$
}

\begin{abstract}
ABSTRAK: Plastik biodegradable yang terbuat dari pati merupakan plastik yang ramah lingkungan untuk mengatasi limbah dari sampah plastik. Pati yang digunakan dalam penelitian ini berasal dari bonggol pisang, tongkol jagung,dan enceng gondok. Gliserol yang terbuat dari minyak bekas yang didaur ulang juga ditambahkan sebagai pemlastis untuk memperoleh plastik yang lebih elastis.Penelitian ini bertujuan untuk mengetahui gugus fungsi, sifat fisis dan mekanis plastik biodegrdable. Variasi konsentrasi antara pati dan gliserol yang digunakan yaitu 100:0; 85:15; $70: 30(\mathrm{~b} / \mathrm{v})$. Pada konsentrasi gliserol $15 \%$ jenis pati bonggol pisang memiliki nilai terbaik untuk kuat tarik sebesar 5,77 MPa dan enceng gondok memiliki modulus young yaitu 0,14 MPa. Uji titik leleh terbaik pada sampel bonggol pisang yang tidak ditambahkan gliserol yaitu $201,110^{\circ} \mathrm{C}$. Nilai elongasi dan swelling terbesar pada sampel tanpa gliserol yaitu enceng gondok sebesar 5,17 \%, dan 95,77 \%. Pada uji FTIR terdapat gugus fungsi berupa O-H alkohol fenol, $\mathrm{N}-\mathrm{H}$ dan $\mathrm{C}-\mathrm{H}$ asam karboksilat dan ammonium, $\mathrm{C} \equiv \mathrm{C}$ asetilen, $\mathrm{C}-\mathrm{O}$ eter, sehingga bahan tersebut mudah terdegradasi oleh bakteri EM4 pada hari ke-8 karena penyusunnya merupakan senyawa organik. Pada sampel tongkol jagung tanpa penambahan gliserol mudah terdegradasi dan jumlah koloni yang tumbuh sangat banyak yaitu $33,67 \times 10^{1}$. Plastik yang dihasilkan memenuhi standart plastik PLA.
\end{abstract}

Kata Kunci: Gliserol; Pati; Bonggol Pisang; Tongkol jagung; Enceng Gondok; Mekanis Plastik; Biodegradable.

\begin{abstract}
Biodegradable plastics made from starch is environmentally friendly plastics for dealing with the waste of plastic trash. The used starch in this study came from banana weevil, corn cobs, and water hyacinth. Glycerol made from recycled used oil was also added as a plasticizer to obtain a more elastic plastic. The Purpose of this research is to determine the functional groups, physical and mechanical properties of biodegradable plastics. The variations between starch and glycerol were $100: 0 ; 85: 15 ; 70: 30$ (\% w / v ). Banana weevil has the best value on the tensile strength $5.77 \mathrm{MPa}$ and on young 's modulus of water hyacinth has the 0.14 Mpa at $15 \%$ glycerol concentrations. The best melting point of banana weevil without glycerol is $201.110^{\circ} \mathrm{C}$. The highest Elongation and swelling were pointed out by water hyacint without glycerol that were $5,17 \%$, and $95,77 \%$ respectively. FTIR test presented functional groups such as $\mathrm{O}-\mathrm{H}$ phenol alcohol, $\mathrm{NH}, \mathrm{CH}$ carboxylic acid, ammonium, $\mathrm{C} \equiv \mathrm{C}$ acetilen and $\mathrm{C}-\mathrm{O}$ eter. These materials are easily degraded by bacteria EM4 at day 8 as a constituent of organic compounds. Corn cobs without glycerol was easily degraded and the growing number of colonies was very much that is $33.67 \times 10^{1}$. The resulting plastic is fulfill The PLA standard..
\end{abstract}

Keyword: Plastik biodegradable, konvensional, gliserol, swelling,modulus young

\footnotetext{
${ }^{1}$ Mahasiswa Jurusan Fisika, Fakultas Sains dan Teknologi, UIN Maliki Malang

E-mail: Inayatul_w@yahoo.com

${ }^{2}$ Staf Pengajar pada Jurusan Fisika, Fakultas Sains dan Teknologi UIN Maliki Malang
} 


\section{PENDAHULUAN}

Kerusakan lingkungan adalah perubahan langsung atau tidak langsung terhadap sifat fisik dan atau hayatinya yang telah mengakibatkan lingkungan menjadi tidak berfungsi lagi.Krisis lingkungan dan rusaknya sumber daya alam semata mata adalah akibat kecerobohan dan ketidakpedulian manusia.Hal ini telah menjadi bumerang berupa banjir, tanah longsor, dan kekeringan.Salah satu kerusakan lingkungan adalah penumpukan sampah plastik yang dapat mencemari lingkungan karena plastik merupakan bahan yang tidak dapat membusuk sehingga jika ditimbun dalam penimbunan akhir akan memberikan banyak masalah. Penumpukan kualitas lingkungan yang disebabkan oleh limbah plastik yang tidak dapat terdegradasi dapat dikurangi dengan usaha mendaur ulang, pengurangan penggunaan dan usaha untuk mencari formula baru dan terbarukan agar mudah terdegradasi. Mendaur ulang plastik selain membutuhkn dana besar, plastik yang dihasilkan juga memiliki keterbatasan masa pakai dan kualitas menurun. Salah satu upaya untuk mengurangi penggunaan plastik konvensional adalah dengan cara mengembangkan ke arah plastik alternatif yang lebih ramah lingkungan. Penelitian yang berkembang saat ini salah satunya adalah plastik biodegradable. Plastik biodegradable dapat diproduksi dari material mentah yang banyak mengandung selulosa, pati atau karbohidrat lain. Jenis plastik biodegradable dapat mengalami penguraian yang lebih cepatdibandingkan dengan plastik non-biodegradable, sehingga plastik biodegradable tidak akan mengganggu keseimbangan alam. Keuntungan lain dari plastikbiodegradable ketika dibuang ke alam akan mempercepat kesuburan tanah. Tumbuhan yang digunakan pada penelitian ini adalah bagian dari pohon pisang yaitu bonggol pisang.Selain itu juga memanfaatkan tongkol jagung dan enceng gondok. Meskipun ketiga jenis pati tersebut memiliki struktur kimia yang sama, namun kandungan dari tiap bagian tumbuhan tersebut berbeda-beda. Ada yang terdapat glukosa maupun karbohidrat.Besar prosentase dari pati bonggol pisang, tongkol jagung, maupun enceng gondok berbeda.Bonggol pisang memiliki komposisi berupa $76 \%$ pati, $20 \%$ air, dan $4 \%$ bahan lainnya (10).Kandungan pati tongkol jagung sebesar $0,014 \%$ dan selulosa sebesar $41 \%$. Dalam keadaan kering enceng gondok mengandung protein kasar 13,03 \% dan serat kasar 20,6 \%. Pati merupakan bahan utama dalam pembuatan plastik biodegradable dan mempengaruhi sifat fisis pada plastik. Sehingga dapat mempercepat proses biodegradasi atau waktu terurainya plastik biodegradable. Hal ini dapat dibuktikan pada penelitian sebelumnya yang dilakukan oleh Wafiroh dkk (2010) menyatakan bahwa variasi komposisi pati dan gliserol (plasticizer) berpengaruh terhadap sifat mekanik dan kimia plastik biodegradable (8). Semakin besar konsentrasi pati dan plasticizer maka nilai sifat kuat tarik semakin menurun. Pada proses pembuatan plastik biodegraable diperlukan pula gliserol untuk meningkatkan sifat mekanik yang dimiliki. Penggunaan gliserol dalam pembuatan plastik biodegradable lebih unggul. Karena tidak ada gliserol yang menguap dalam proses pembuatan plastik sehingga memudahkan proses mekanis dan menjaga produk dari penguapan dibandingkan produk plasticizer lainnya. Gliserol sesuai digunakan sebagai pemlastis pada pembuatan plastik berbasis pati. Semakin besar nilai plasticizer maka prosentase swelling atau ketahanan terhadap air akan meningkat (7). Pembuatan gliserol memanfaatkan minyak goreng bekas untuk dimanfaatkan kembali menjadi bahan yang memiliki nilai guna.Sehingga untuk 
memperbaiki sifat fisis dan mekanis plastik biodegradable penelitian ini menggunakan variasi kosentrasi dari pati dan gliserol dengan tiga jenis pati yang berbeda berupa bonggol pisang, tongkol jagung, dan enceng gondok.

Tujuan dalam penelitian ini antara lain adalah Untuk mengetahui gugus fungsi dari plastik biodegradable, untuk mengetahui pengaruh variasi komposisi gliserol dan pati (bonggol pisang,tongkol jagung dan enceng gondok) terhadap uji degradasi dari plastik biodegradable, dan mengetahui sifat mekanik plastik biodegradable dengan pengaruh variasi komposisi gliserol dan pati (bonggol pisang, tongkol jagung dan enceng gondok).

Pada penelitian ini terdiri dari tiga proses yaitu pembuatan gliserol, pembuatan pati, dan pembuatan plastik biodegradable. Proses pembuatan gliserol dengan cara Minyak jelantah sebanyak $500 \mathrm{ml}$ disaring dan dipanaskan ke dalam labu leher tiga sampai suhu $60{ }^{\circ} \mathrm{C}$. Kemudian $\mathrm{KOH}$ 1,5 gram dilarutkan ke dalam metanol $100 \mathrm{ml}$ dan dimasukkan ke dalam labu leher tiga bersamaan dengan minyak jelantah sampai suhu $60{ }^{\circ} \mathrm{C}$ selama 60 menit (5). Pemberian $\mathrm{KOH}$ berfungsi mempercepat proses reaksi yang terjadi di dalam labu leher tiga sehingga ketiga bahan tersebut bisa tercampur dan warnanya menjadi coklat tua dan bersih. Pengambilan sampel 10 kali tiap 10 menit dengan masing-masing pengambilan $10 \mathrm{ml}$. Sampel didiamkan di dalam beaker glass $25 \mathrm{ml}$ selama 1 malam.Hal ini bertujuan untuk membentuk dua lapisan antara gliserol dan bioetanol.Larutan tersebut didiamkan dan dipisahkan dengan menggunakan corong pemisah.Larutan gliserol yang terbentuk berwarna coklat tua, sedangkan bioetanol berwarna kuning jernih.

Pembuatan pati bonggol pisang dengan cara memisahkan bonggol pisang dari batangnya. Kemudian bonggol pisang dicacah dan direndam ke dalam larutan asam sitrat $50 \%$ (w/v) selama 10 menit(6). Hal ini bertujuan untuk menghilangkan enzim browning (warna biru) pada bonggol pisang. Bonggol pisang dipanaskan di bawah terik matahari dan direndam di dalam air sehinggamudah hancur ketika diblender. Bubur tersebut disaring dan diperoleh endapan.Kemudian ditambahkan dengan air dan diendapkan lagi selama 30 menit sehingga diperoleh pati.Selanjutnya pati di keringkan di bawah panas matahari dan ditumbuk menjadi serbuk.

Pembuatan pati tongkol jagung dilakukan dengan cara tongkol jagung dipotong kecilkecil kemudian diblender dan ampasnya diperas dengan kain saring. Setelah itu didiamkan selama satu hari untuk menghasilkan endapan pati.Kemudian pati dikeringkan di bawah terik matahari untuk menghilangkan kandungan air di dalamnya dan ditumbuk dengan mortar hingga halus (3).

Pati enceng gondok didapatkan dengan cara bonggol enceng gondok dibersihkan dan dipotong untuk diblender sampai halus. Bubur enceng gondok yang dihasilkan diperas dan didiamkan selama satu hari.Endapan yang dihasilkan disaring dengan menggunakan kertas saring dan dikeringkan di bawah sinar matahari. Tujuannya untuk menghilangkan kadar air yang ada di dalam pati. Setelah itu pati ditumbuk dengan mortar hingga halus.

Pati kemudian diproses lanjut untuk dibentuk menjadi plastik biodegradable. Pembuatan plastik biodegradablemenggunakanperbandingan pati dangliserol 100:0; 85:15; 70:30 (\% b/v).Lalu ditambahkan asam asetat $3 \mathrm{ml}$ dan caragenan gram ke dalam $50 \mathrm{ml}$ aquades. Fungsi dari penambahan asam asetat sebagai pelarut pada adonan plastik dan Caragenan sebagai pembentuk gel maupun penambah ketebalan.Beberapa bahan tersebut 
(asam asetat, aquades, dan caragenan) dicampur dan diaduk dengan magnetic stirer selama 15 menit sampai homogen hingga adonan mengental seperti gel atau agar-agar. Masingmasing jenis pati mengalami proses glatinisasi berbeda-beda, untuk bonggol pisang dan enceng gondok suhu yang digunakan sebesar $70{ }^{\circ} \mathrm{C}$ sedangkan tongkol jagung sebesar 80 ${ }^{\circ} \mathrm{C}$ (2). Selain itu proses glatinisasi maksimum $80{ }^{\circ} \mathrm{C}$ agar pati tidak pecah. Kemudian adonan plastik dituangkan ke dalam cetakan kaca dan dikeringkan di bawah terik matahari samnj pai adonan kering dan membentuk plastik.Gambar 1 merupakan beberapa sampel plastik biodegradable dari berbagai jenis pati dan variasi komposisi.

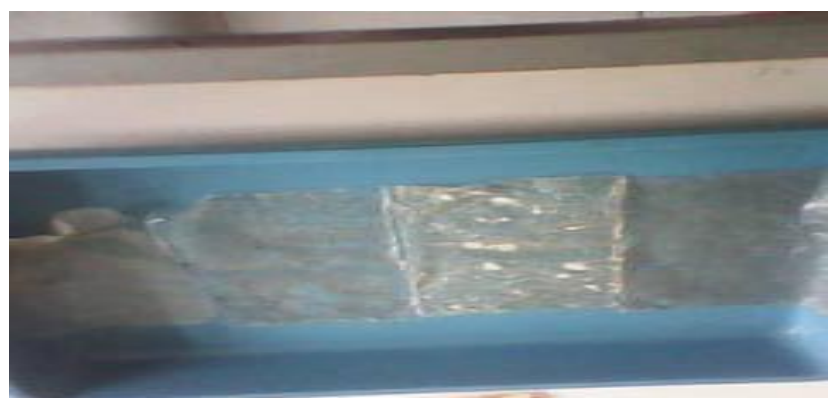

Gambar 1. Sampel Plastik Biodegradable

\section{HASIL DAN PEMBAHASAN}

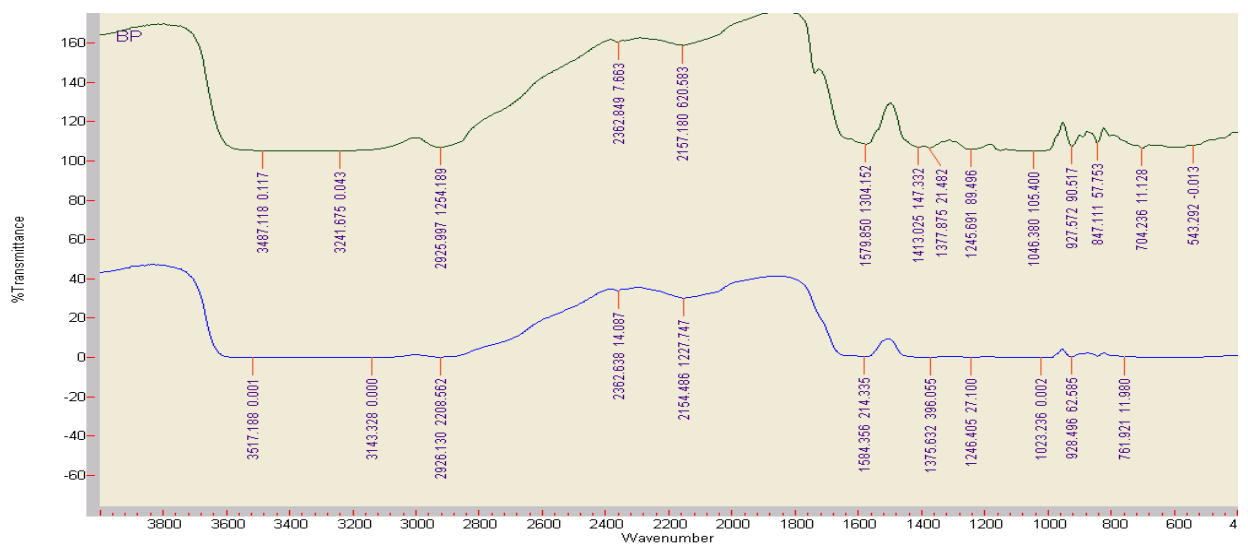

Gambar 2. a) gugus fungsi untuk plastik biodegradablejenis pati enceng gondok dengan variasi komposisi $85 \%$ dan $15 \%$. b) gugus fungsi untuk plastik

biodegradablejenis pati bonggol pisang dengan variasi komposisi 85\% dan $15 \%$.

Gambar 2 merupakan pengujian FTIR terhadap sampel plastik biodegradableyang menggunakan bahan dasar pati yang berbeda dengan variasi konsentrasi pati dan gliserol seperti pada tabel 1 .

Tabel 1. Gugus fungsi yang terbentuk pada plastik biodegradable

\begin{tabular}{cccc}
\hline \multicolumn{2}{c}{ Bilangan gelombang $\left(\mathrm{cm}^{-1}\right)$} & & \\
\cline { 1 - 2 } Pati bonggol & Pati enceng & Gugus fungsi & Nama senyawa \\
pisang dengan & gondok dengan & & \\
variasi pati $85 \%$ & variasi pati 85\% & & \\
dan gliserol 15\% & dan gliserol 15\% & & \\
\hline
\end{tabular}




\begin{tabular}{|c|c|c|c|}
\hline 3517,188 & 3487,118 & $\mathrm{O}-\mathrm{H}$ & Alkohol, fenol \\
\hline 3143,328 & 3241,675 & N-H \& C-H & $\begin{array}{l}\text { Asam karboksilat } \\
\text { dan amonium }\end{array}$ \\
\hline 2926,130 & 2925,997 & N-H \& C-H & $\begin{array}{l}\text { Asam karboksilat } \\
\text { dan amonium }\end{array}$ \\
\hline 2362,638 & 2362,849 & N-H \& C-H & $\begin{array}{c}\text { Asam karboksilat } \\
\text { dan amonium }\end{array}$ \\
\hline 2154,486 & 2157,180 & $\mathrm{C} \equiv \mathrm{C}$ & Asetilen, Alkuna \\
\hline 1584,356 & 1579,850 & $\mathrm{C}=\mathrm{O} \& \mathrm{C}-\mathrm{O}$ & Anion karboksilat \\
\hline- & 1413,025 & $\mathrm{O}-\mathrm{H}$ & Alkohol, fenol \\
\hline 1375,632 & 1377,875 & $\mathrm{O}-\mathrm{H}$ & Alkohol, fenol \\
\hline $\begin{array}{c}\text { Bilangan gel } \\
\text { Pati bonggol } \\
\text { pisang dengan } \\
\text { variasi pati } 85 \% \\
\text { dan gliserol } 15 \%\end{array}$ & $\begin{array}{l}\text { abang }(\mathrm{cm}-1) \\
\text { Pati enceng } \\
\text { gondok dengan } \\
\text { variasi pati } 85 \% \\
\text { dan gliserol } 15 \%\end{array}$ & Gugus fungsi & Nama senyawa \\
\hline 1246,405 & 1245,691 & $\mathrm{C}-\mathrm{O}-\mathrm{C}$ & $\begin{array}{c}\text { Eter, } \\
\text { epksida,peroksida } \\
\text { (aril eter tak simetri) }\end{array}$ \\
\hline 1023,236 & 1046,380 & $\mathrm{C}-\mathrm{O}$ & $\begin{array}{l}\text { Alkohol alkohol } \\
\text { primer }\end{array}$ \\
\hline 928,496 & 927,572 & $\mathrm{C}-\mathrm{C} \& \mathrm{C}-\mathrm{O}$ & $\begin{array}{l}\text { Eter, epksida, } \\
\text { peroksida }\end{array}$ \\
\hline- & 847,111 & $\mathrm{~N}-\mathrm{H}$ & $\begin{array}{l}\text { Amina primer \& } \\
\text { sekunder (cairan) }\end{array}$ \\
\hline 761,921 & 704,236 & $\mathrm{~N}-\mathrm{H}$ & $\begin{array}{c}\text { Amina primer \& } \\
\text { sekunder (cairan) }\end{array}$ \\
\hline- & 543,292 & $\mathrm{C}-\mathrm{Cl}$ & $\begin{array}{c}\text { Senyawa } \\
\text { terkarbonisasi }\end{array}$ \\
\hline
\end{tabular}

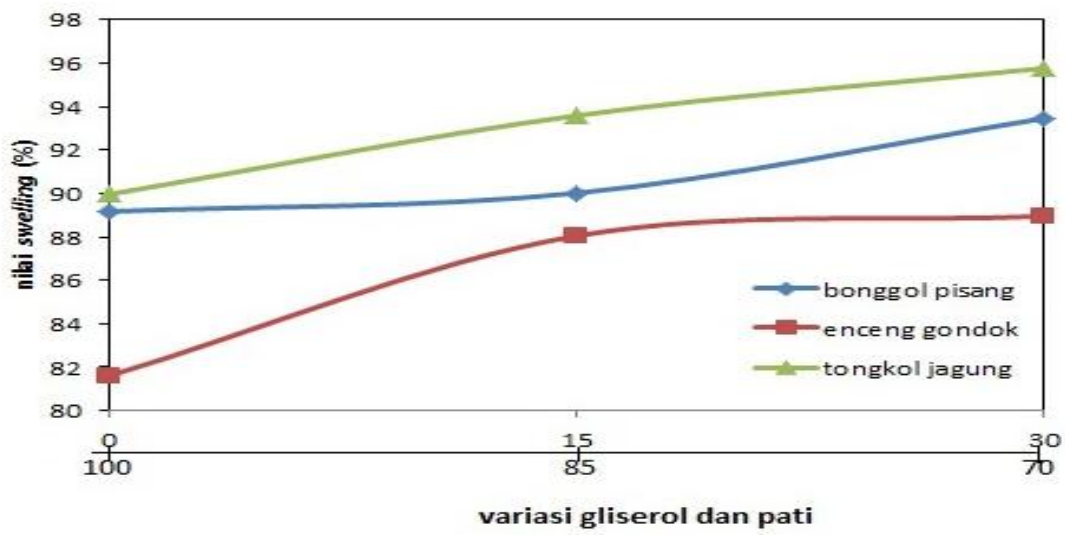

gliserol (\%)

pati $(\%)$

Gambar 3. Grafik hubungan variasi komposisi pati dan gliserol terhadap nilai rata-rata uji swelling pada plastik biodegradable

Gambar 3 dapat diketahui bahwa semakin banyak gliserol yang ditambahkan maka jumlah air yang diserap semakin banyak. Penyerapan tertinggi sebesar 95,77\% dengan jenis pati tongkol jagung dengan konsentrasi pati 70\% dan gliserol 30\%. Menurut Darni et. al(2009) gliserol memiliki strukur kimia berupa ikatan hidrogen yang kuat dan sulit untuk bergabung dengan air (1).Namun penambahan gliserol yang berlebih mampu 
meningkatkan daya serap gliserol.Hal ini terjadi karena ikatan hidrogen dalam molekul gliserol cenderung untuk membentuk ikatan hidrogen intramolekuler termasuk dengan molekul air. Jadi dapat dikatakan bahwa plastik yang dihasilkan bersifat hidrofilik

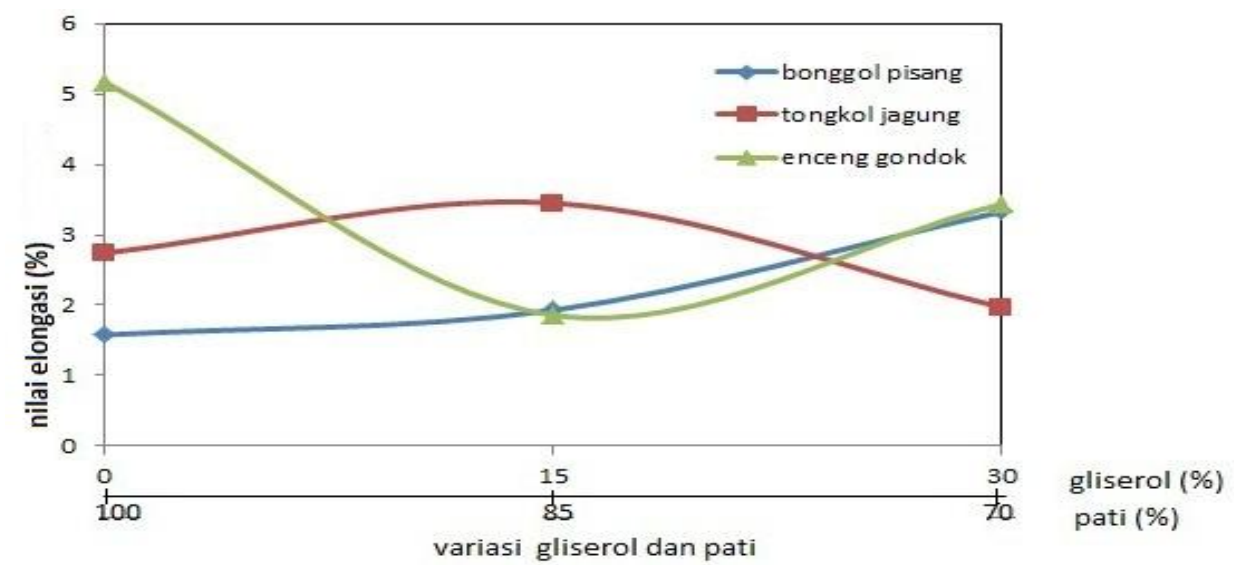

Gambar 4. Grafik hubungan variasi komposisi pati dan gliserol terhadap nilai rata-rata elongasi plastik biodegradable

Penambahan gliserol dan pati juga mempengaruhi kuat tarik.Kuat tarik merupakan salah satu uji untuk mengetahui tegangan maksimum suatu bahan. Kuat tarik terbaik dimiliki oleh Janis pati bonggol pisang dengan variasi pati $85 \%$ dan gliserol $15 \%$ sebesar 5,77 MPa. Nilai kuat tarik plastik biodegradable tersebut cukup mendekati nilai kuat tarik plastik biodegradable sebesar $10-100 \mathrm{MPa}$. Besarnya kuat tarik plastik biodegradabledipengaruhi oleh besarnya konsentrasi gliserol. Semakin besar konsentrasi gliserol maka semakin turun kuat tariknya (4). Penambahan gliserol akan meningkatkan penambahan elongasi dan menurunkan kuat tarik. Nilai modulus youngsebagai ukuran kekakuan suatu bahan polimer masih jauh dari standar plastik konvensional maupun plastik biodegradable.

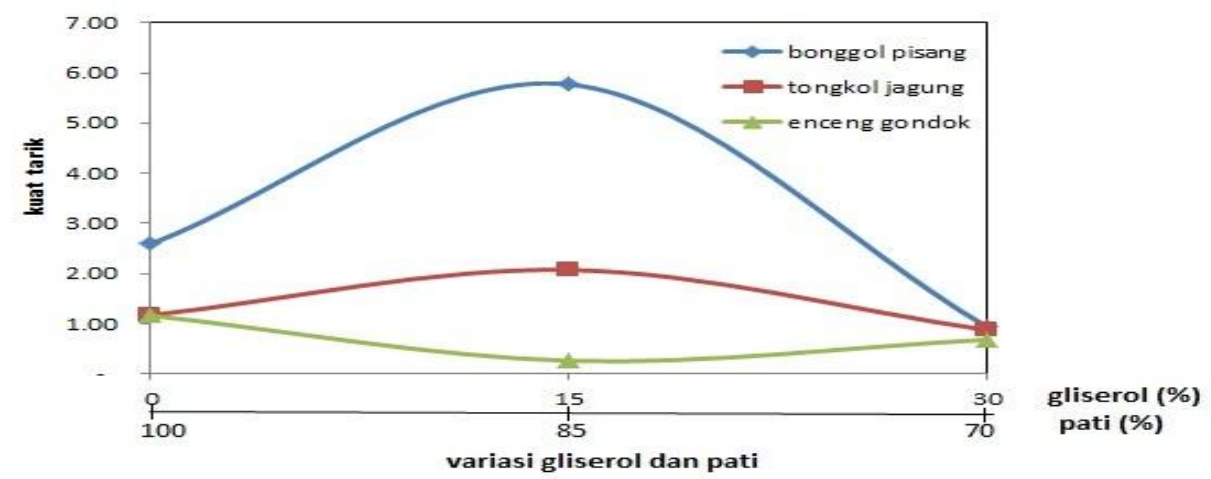

Gambar 5. Hasil pengaruh variasi komposisi gliserol dan pati terhadap rata-rata kuat tarik

Kekuatan tarik $\left(\mathrm{kgf} / \mathrm{mm}^{2}\right)=\underset{\text { Luas penampang }(\mathrm{A})}{\text { Gaya kuat } \operatorname{tarik}(\mathrm{F})}$

$1 \mathrm{kgf} / \mathrm{mm}^{2}=9.80665 \mathrm{Mpa}$ Luas penampang (A)

Nilai modulus young dapat dihitung dengan persamaan 2:

Modulus Young $=\frac{\text { nilai kuat tarik }}{\text { nilai elongasi }}$. 


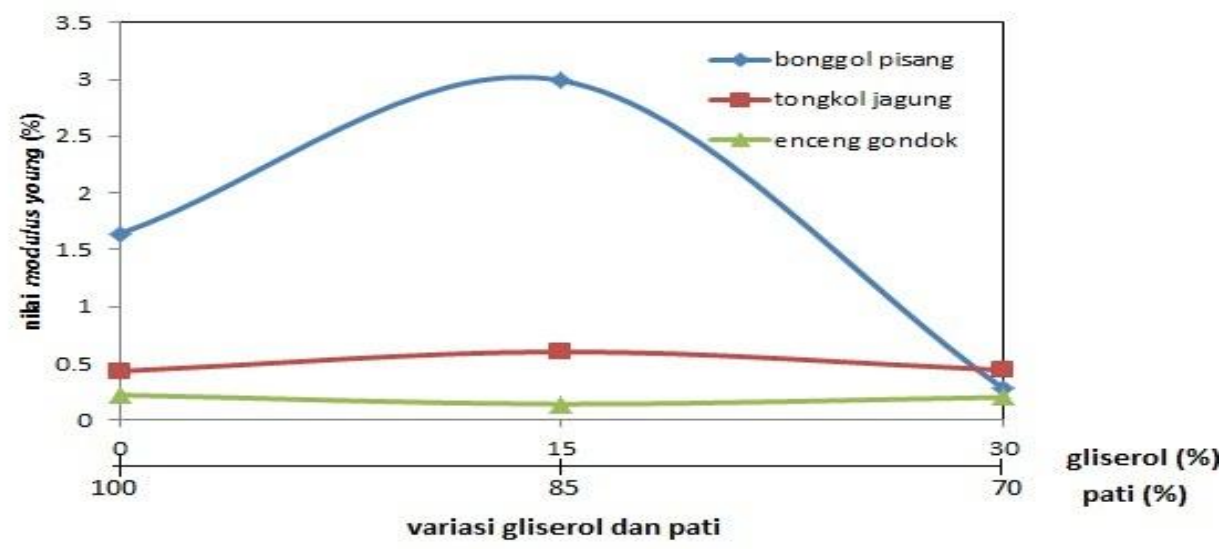

Gambar 6. Hasil rata-rata nilai modulus young plastik biodegradable

Nilai uji kuat tarik dan elongasi yang naik turun disebabkan oleh beberapa faktor misalnya pencampuran yang kurang homogen sehingga penyisipan bahan pemlastis ke dalam matriks plastik komposit belum berlangsung sempurna dan perpanjangan putus yang dihasilkan tidak maksimal.

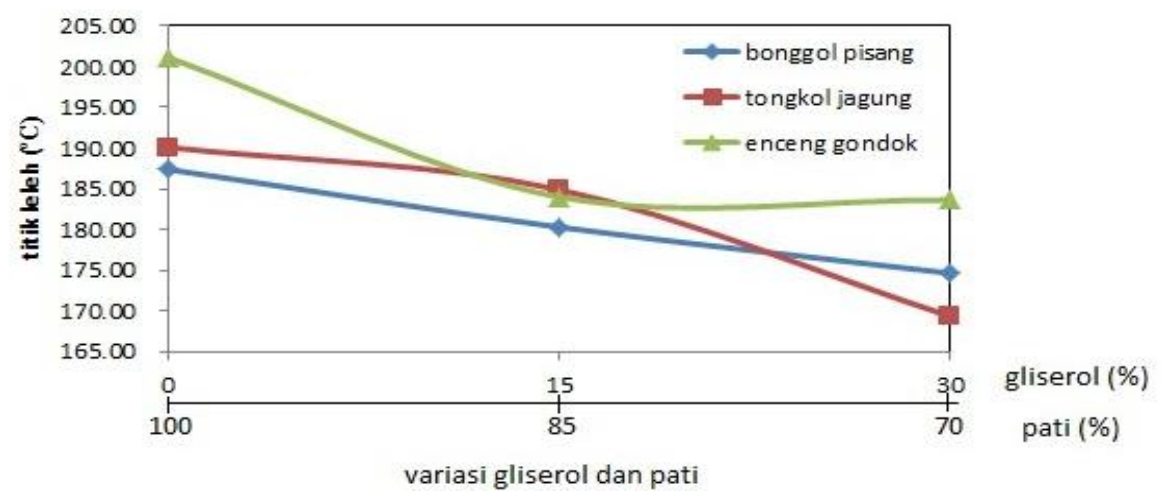

Gambar 7. Grafik hubungan variasi komposisi pati da gliserol terhadap rata-rata titik leleh sampel plastik biodegradable

Selain itu terdapat gugus fungsi $\mathrm{C}=\mathrm{O}$ dan $\mathrm{C}-\mathrm{O}-\mathrm{C}$ yang menunjukan struktur pati. Karena kandungan pati dapat mempercepat proses degradasi sampel plastik. Hal ini sesuai dengan hasil uji biodegradasi pada tabel 4.10. Pada bilangan gelombang $847,111 \mathrm{~cm}^{-1}$ untuk jenis pati bonggol pisang terjadi pergeseran puncak, sehingga vibrasi terjadi di $761,921 \mathrm{~cm}^{-1}$. Pada puncak 543,292 terdapat gugus fungsi C-Cl di sampel jenis pati enceng gondok.Gugus fungsi tersebut memiliki titik didih yang tinggi.Demikian pula sifat dari gliserol memiiki titik didih yang tinggi.Adanya kandungan gliserol pada puncak sampel dari pati enceng gondok yang mengakibatkan nilai kuat tarik menurun.Terdapat banyak gugus fungsi $\mathrm{O}-\mathrm{H}$ yang terbentuk dikarenakan penambahan gliserol pada tiap-tiap sampel.Data kandungan O-H pada tabel 1 dapat didukung daripernyataan Wahyu (2008) pada hasil penelitiannya bahwa naik dan turunnya gugus $\mathrm{O}-\mathrm{H}$ dalam sampel plastik akan sesuai dengan titik leleh sampel tersebut (9). Karena semakin kecil kandungan O-H maka titik leleh yang dimiliki sampel juga akan semakin rendah. Begitu pula sebaliknya, semakin besar kandungan $\mathrm{O}-\mathrm{H}$ yang terindikasi semakin banyak ikatan hidrogen dalam sampel sehingga semakin tinggi pula titik didih yang dimiliki sampel plastik. 


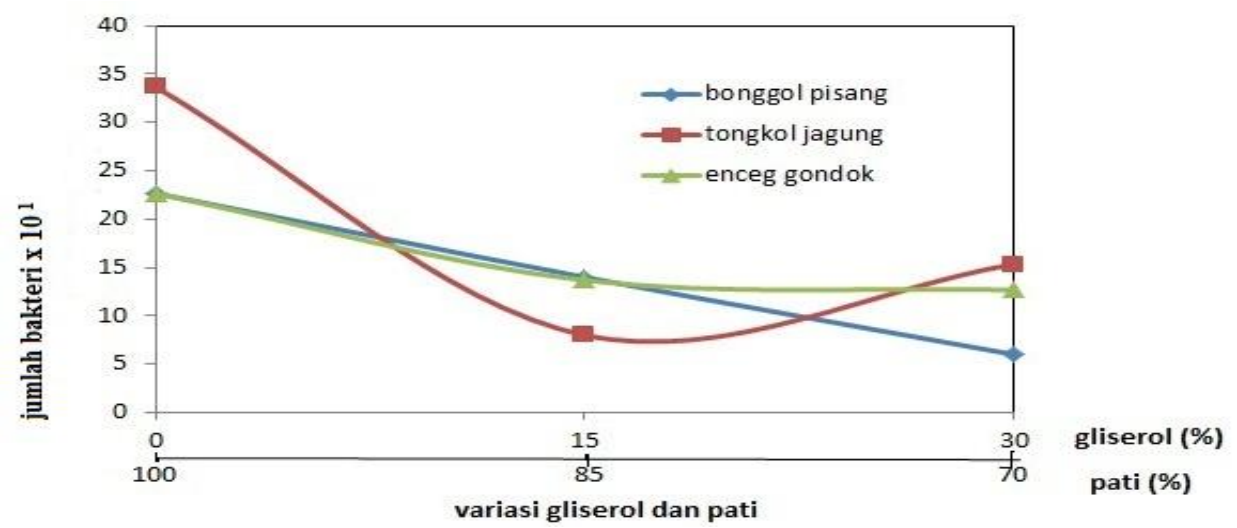

Gambar 8. Hubungan variasi komposisi pati dan gliserol terhadap rata-rata jumlah koloni sampel plastik biodegradablepada uji biodegradasi

$$
\Sigma \mathrm{sel} / \mathrm{ml}=\text { jumlah koloni } \mathrm{x} \frac{1}{\text { faktor pengenceran }} \mathrm{x} \frac{\text { volume bakteri }}{1000} .
$$

Berdasarkan beberapa hasil pengujian, adapun perbandingan nilai hasil penelitian dengan nilai standar plastik PLA terdapat pada tabel 2 yang memiliki nilai yang sama. Hasil pada plastik biodegradable didapatkan dari hasil yang terbaik dari masing-masing pengujian. Selain itu plastik PLA dapat terdegradasi secara alami oleh panas, cahaya, bakteri, maupun oleh proses hidrolisis. Sedangkan dalam penelitian ini plastik yang dihasilkan terdegradasi oleh mikroba EM4 dalam waktu 8 hari.

Tabel 2. Perbandingan nilai standart PLA dengan plastik biodegradable yang dihasilkan

\begin{tabular}{lc}
\hline \multicolumn{2}{c}{ Parameter PLA Plastik biodegradable yang dihasilkan } \\
\hline Titik leleh $\left({ }^{\circ} \mathrm{C}\right)$ & $130-215201,110$ \\
Elongasi $(\%)$ & $2,55,17$ \\
Kuat tarik (MPa) & $5-1005,77$ \\
Modulus young (MPa) & $4,90,14$ \\
\hline
\end{tabular}

Aplikasi plastik yang dihasilkan pada penelitian ini dapat digunakan sebagai pembungkus makanan.Sedangkan aplikasi PLA dapat digunakan untuk pembuatan plastik biodegradable dan aplikasi medis sepertisistem penyaluran obat, benang bedah maupun pembuatan organ buatan.

\section{KESIMPULAN}

Berdasarkan pengaruh penambahan variasi komposisi pati dan gliserol dengan jenis pati yang berbeda didapatkan kesimpulan sebagai berikut:

1. Pengujian FTIR pada variasi konsentrasi pati enceng gondok dan gliserol 85:15 (\% b/v) di bilangan 543,292 $\mathrm{cm}^{-1}$ yang merupakan gugus fungsi dari C-Cl. Sedangkan sampel pati bonggol pisang tidak terdapat gugus fungsi tersebut. Puncak $847,111 \mathrm{~cm}^{-1}$ pada sampel enceng gondok terdapat gugus fungsi N-H. Akan tetapi pada plastik berbahan dasar bonggol pisang gugus fungsi N-H bergeser ke puncak 761,921 $\mathrm{cm}^{-1}$.

2. Pada pengujian biodegradasi, jumlah koloni semakin berkurang dengan bertambahnya konsentrasi pada gliserol. Pada sampel tongkol jagung tanpa penambahan gliserol 
mudah terdegradasi sehingga jumlah koloni yang tumbuh sangat banyak yaitu 33,67. Selain itu Pada uji FTIR terdapat gugus fungsi berupa O-H alkohol fenol, N-H dan C$\mathrm{H}$ asam karboksilat dan ammonium, $\mathrm{C} \equiv \mathrm{C}$ asetilen, $\mathrm{C}-\mathrm{O}$ eter, sehingga bahan tersebut mudah terdegradasi oleh bakteri EM4 pada hari ke-8 karena penyusunnya merupakan senyawa organik.

3. Penambahan pati dan gliserol mempengaruhi sifat mekanik plastik. Semakin besar konsentrasi gliserol maka nilai titik leleh, kuat tarik dan modulus young semakin menurun. Uji titik leleh terbaik pada sampel bonggol pisang yang tidak ditambahkan gliserol yaitu $201,110^{\circ} \mathrm{C}$. Pada konsentrasi gliserol $15 \%$ jenis pati bonggol pisang memiliki nilai terbaik untuk kuat tarik sebesar 5,77 MPa dan enceng gondok memiliki modulus young yaitu 0,14 MPa. Tetapi nilai elongasi dan swelling semakin meningkat. Nilai terbesar untuk elongasi adalah 5,17 \% terdapat pada pati enceng gondok tanpa penambahan gliserol. Nilai terbesar untuk swelling adalah tongkol jagung 70:30 (\% b/v) yaitu 95,77 \%. Sehingga plastik biodegradable yang dihasilkan memenuhi standart pada plastik jenis PLA.

\section{DAFTAR PUSTAKA}

(1) Darni,Yuli, dkk. Sintesa Bioplastik dari Pati Pisang dan Gelatin dengan Plasticizer Gliserol. Universitas Lampung: Seminar Nasional Sains dan Teknologi-II. 2008.

(2) Dziendzic, S. The Technology of Starch Production. London: Blackie Academic. 1995.

(3) Iryanto. Hidrolisis Tongkol Jagung. Bandung. 1995.

(4) Krochta dan De Mulder Johnston. Edible and Biodegradable Polymers Film: Changes \& Opportunities. Food Technology 51. 1997.

(5) Kwartiningsih, dkk. Pengaruh Temperatur Terhadap Kinetika Reaksi Metanolisis Minyak Jelantah Menjadi Biodiesel (Ditinjau Sebagai Reaksi Homogen). Surakarta: UNS. 2007.Vol. 6 No. 2 Juli 2007: 71-74.

(6) Rahmawati, dkk. Pemanfaatan Kulit Pisang Raja (Musa sapientum) dalamPembuatan Plastik Biodegradable Dengan Plasticizer Gliserin Dari Minyak Jelantah. Laporan Kemajuan Program Kreativitas Mahasiswa. Bandung: ITB. 2011.

(7) Stevens, Malcom P. Kimia Polimer. Jakarta: Pradnya Paramita. 2007.

(8) Wafiroh, dkk. Pembuatan dan karakterisasi edible film dari komposit kitosan-pati garut (maranta arundinaceace L) dengan pemlastis asam laurat. 2010.

(9) Wahyu, Maulana Karnadidjaja. Pemanfaatan Pati Singkong Sebagai Bahan Baku Edible Film. LKTI: Bandung Universitas Padjadjaran. 2008.

(10) Yuanita,dkk. Pabrik Sorbitol dari Bonggol Pisang (Musa Paradisiacal) dengan Proses Hidrogenasi Katalik. Jurnal Ilmiah Teknik Kimia. Surabaya: ITS. 2008 